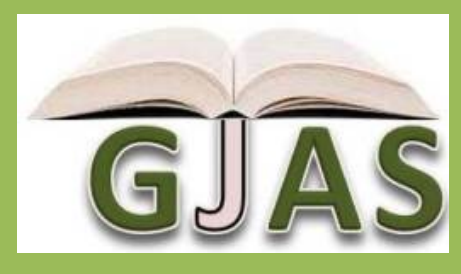

\title{
Economic Analysis of Vegetable Production by Rural Women in Iwo Zone of Osun State, Nigeria
}

\section{${ }^{1 *}$ Busari Ahmed O, ${ }^{2}$ Idris-Adeniyi K.M. and ${ }^{3}$ Oyekale J.O}

\author{
Department of Agricultural Economics and Extension Osun State University, College of \\ Agriculture, Ejigbo Campus
}

Article No.: 110512231

DOI: 10.15580/GJAS.2013.1.110512231

Submitted: 11/05/2012

Accepted: 25/12/2012

Published: 20/01/2013

${ }^{*}$ Corresponding Author

Busari Ahmed O

E-mail:

busariahmed2008@yahoo.com, hamed.busari@uniosun.edu.ng

Keywords:

Rural women, Vegetable

Production, Agricultural

productivity, Economic

development
This study analyzed the effects of socio-economic characteristics of women vegetable farmers on their gross margin in Iwo Zone of Osun State of Nigeria.

Multistage sampling was used to select one hundred and thirty (130) women vegetable farmers as the sample for the study. Data was collected by means of structured interview schedule. Information was obtained on age, marital status, years of formal education, farming experience, land ownership, costs and revenue. Percentages, Means and Frequencies were the main descriptive statistical tools utilized. While the inferential statistics used are Analysis of Variance (ANOVA) and Multiple Regression Analysis.

The findings revealed that majority $(76.15 \%)$ of women vegetable farmers fall between the ages of 41-60 years with a mean age of 50.85 years. $42.31 \%$ of women vegetable farmers had primary education. While $24.61 \%$ receive secondary education. None of the women vegetable farmers receive post secondary education. Majority (31.54\%) of the women vegetable farmers acquired the land they are using for farming through gift. $22.31 \%$ of the women vegetable farmer obtained their land through inheritance, while $15.38 \%$ of the women vegetable farmers acquired their land through purchase, tenancy and other means.

All $(100 \%)$ of the women vegetable farmers are married. The mean gross margin of women vegetable farmers is \#33047. Four variables were significant at $5 \%$ level. These are years of formal education, land ownership, cost of chemicals and cost of labour. There is no significant difference in the socio-economic characteristics of women vegetable farmers in the study area. Also, there is no significant difference in the gross margin of women vegetable farmers group in the study area.

The mean gross margin (\#33047) obtained from the study indicated that vegetable production is an essential income earner for rural women in the study area.. 


\section{INTRODUCTION}

In the past women contribution to economic development especially in the developing countries was either not recognized or been seriously underestimated. Emphasis has been mainly on women reproductive role than the productive. The reproductive role is unpaid for and is excluded from census and national accounts.

In Nigeria women play important role in agricultural production. In fact, women produce most of the Africa's subsistence food and account for 60 to $80 \%$ of agricultural labour supply (B.T Adeyemi, 1992).

Vegetable (leafy and fruits) are widely cultivated in most parts of sub Sahara Africa, as a cheap and reliable source of protein, vitamins, zinc and iron. They constitute between $30 \%$ and $50 \%$ of iron and vitamins $A$ in resource poor diet. Vegetable production in Nigeria is characterized by use of crude implements, non availability of inputs, illiteracy, expensive and complex technologies. (Mofeke et al., 2003).

Leafy vegetables are an important feature of Nigerian's diet that a traditional meal without it is assumed to be incomplete. In developing countries, the consumption of vegetables is generally lower than the FAO recommendation of $75 \mathrm{~kg}$ per year in habitant $(206 \mathrm{~g}$ per day per capita) ( Badmus and Yekini, 2011).

In Nigeria, vegetable production has been on -going for decades, providing employment and income for the increasing population especially during the long dry season. However production is constrained by inadequate infrastructure, agronomic and socioeconomic variables (Sabo and Zira, 2008).

It has been widely demonstrated that rural women, as well as men, throughout the world are engaged in a range of productive activities essential to household welfare, agricultural productivity, and economic growth. Yet women's substantial contribution continues to be systematically marginalized and undervalued in conventional agricultural and economic analyses and policies, while men's contribution remains the central, often the sole, focus of attention.

Women are typically, and wrongly, still characterized as "economically inactive" in statistical surveys of agriculture, a result that tells us more about survey methodology than about reality (Janelid, 1975). Policy makers and administrators typically still assume (in the face of the empirical data) that men are the farmers and women play only "supportive role" as farmers' wives (Samanta, 1994).

$Y=X_{1}+X_{2}+X_{3}+X_{4}+X_{5}+X_{6}+X_{7}$

Where

$\mathrm{Y}=$ Gross Margin which is estimated as

$Y=T R-T C$

$\mathrm{TR}=$ total revenue

$\mathrm{TC}=$ total cost
The official definition of a farmer in Nigeria in 1965, for example, was given as "an adult male" who has the right to the produce of a farm. Women are not classified as farmers (FOS, 1966). Yet among many studies of rural women in Nigeria (WORDOC, 1988), Akor (1990) found that $92 \%$ of the surveyed northern rural women gave farming as their primary or secondary occupation. Of these, $74 \%$ owned or worked their own separate plots.

This study thus, analyzed the social and economic characteristics of women vegetable farmers in Iwo Zone of Osun State of Nigeria.

\section{MATERIALS AND METHOD}

The study was conducted in Iwo Zone of Osun State Agricultural Development Programme (OSSADEP). The zone is made up of ten (10) Local Government Areas namely; Ola Oluwa, Iwo, Aiyedire, Ejigbo, Isokan, Oriade, Egbedore, Ayedade, Ede North and Ede South.

Multi stage sampling technique was used to select sample for the study. Four (4) Local Governments Areas were purposively selected for the study. These are Ola Oluwa, Iwo, Aiyedire and Ejigbo. Seven (7) towns were purposively selected from the Local Government Areas based on high concentration of women vegetable farmers in these towns. These towns are Bode Osi, Amere, Ogbaagba, Papa, Ileogbo, Asamu and Masifa. One hundred and thirty (130) women vegetable farmers were randomly selected from the towns to make the sample for the study.

Data in this study were collected through a structured interview schedule which was administered to women vegetables farmers. Information on age, marital status, years of formal education, farming experience, costs and revenue were obtained from the vegetable farmers and merged for analysis.

Data in this study was analyzed with both descriptive and inferential statistics. The descriptive statistics that was employed in the study includes Means, Standard Deviation, Frequencies and Percentages. While the inferential statistics utilized are Multiple Regression Analysis and Analysis of Variance (ANOVA).

The empirical model used in the study is specified as follows: 
$X_{1}=$ age in years of the respondents

$\mathrm{X}_{2}=$ years of formal education

$\mathrm{X}_{3}=$ farming experience in years

$\mathrm{X}_{4}=$ dummy variable for land ownership

$\mathrm{X}_{5}=$ price of basket of vegetable

$X_{6}=$ cost of chemicals (fertilizers and insecticides)

$\mathrm{X}_{7}=$ cost of labour

\section{RESULTS AND DISCUSSION}

Demographic and other related characteristics of the Respondents
One of the objectives of the study is to examine demographic and other related characteristics of women vegetable farmers in the study area. The selected characteristics are age, tribe, years of formal education, farming experience, marital status and land ownership. They are hereby discussed.

Age

Table 4.1:Distribution of respondents according to their Age

\begin{tabular}{|l|l|l|}
\hline Age (years) & Frequency & Percentage \\
\hline $31-40$ & 31 & 23.85 \\
\hline $41-50$ & 57 & 43.85 \\
\hline $51-60$ & 42 & 32.30 \\
\hline Total & 130 & 100.00 \\
\hline \multicolumn{2}{|c|}{ Mean Age $=50.85$ years. }
\end{tabular}

Source: Field Survey, 2011.

Table 4.1 shows that the majority $(76.15 \%)$ of women vegetable farmers are between the age of 41-60 years with the highest concentration (43.85\%) found between the range of $41-50$ years. The mean age is 50.85 years.

Tribe

Table 4.2:Distribution of respondents according to Tribe

\begin{tabular}{|l|l|l|}
\hline Tribe & Frequency & Percentage \\
\hline Ibo & 0 & 0 \\
\hline Yoruba & 130 & 100.00 \\
\hline Hausa & 0 & 0 \\
\hline Others & 0 & 0 \\
\hline Total & 130 & 100.00 \\
\hline
\end{tabular}

Source: Field Survey, 2011

Table 4.2 above shows that majority (100\%) of the women vegetable farmers are Yoruba by tribe. This can be attributed to the area of study which is located in the southwestern part of Nigeria.

\section{Years of Formal education}

Table 4.3: Distribution of respondents according to their years of education

\begin{tabular}{|l|l|l|}
\hline Years of education & Frequency & Percentage \\
\hline 0 & 43 & 33.08 \\
\hline $1-6$ & 55 & 42.31 \\
\hline $7-12$ & 32 & 24.61 \\
\hline $13-18$ & 0 & 0 \\
\hline Total & 130 & 100.00 \\
\hline
\end{tabular}

Source: Field Survey, 2011 
Data in Table 4.3 indicates that most (42.31\%) of the women vegetable farmers attended primary school. About $33.08 \%$ receive no form of formal education, while, $24.61 \%$ receive secondary education. None of the women vegetable farmers receives post secondary education.

\section{Farming Experience}

Table 4.4: Distribution of respondents according to their years of Farming Experience

\begin{tabular}{|l|l|l|}
\hline Farming Experience (yrs) & Frequency & Percentage \\
\hline $5-10$ & 54 & 41.54 \\
\hline $11-20$ & 65 & 50.00 \\
\hline $21-30$ & 11 & 8.46 \\
\hline Total & 130 & 100.00 \\
\hline
\end{tabular}

Source: Field Survey, 2011

Table 4.4 shows that majority $(58.46 \%)$ of the women $41.54 \%$ had farming experience of $5-10$ years, while only vegetable farmers had been farming for $11-30$ years. $8.46 \%$ had farming experience of over 20 years.

\section{Marital Status}

Table 4.5: Distribution of respondents according to their marital status

\begin{tabular}{|l|l|l|}
\hline Marital Status & Frequency & Percentage \\
\hline Single & 0 & 0.00 \\
\hline Married & 130 & 100.00 \\
\hline Total & 130 & 100.0 \\
\hline
\end{tabular}

Source: Field Survey, 2011

Table 4.5 indicated that majority (100\%) of the women vegetable farmers are married.

\section{Land Ownership}

Table 4.6: Distribution of respondents according to their land ownership

\begin{tabular}{|l|l|l|}
\hline Land ownership & Frequency & Percentage \\
\hline Inheritance & 29 & 22.31 \\
\hline Purchase & 20 & 15.38 \\
\hline Tenancy & 20 & 15.38 \\
\hline Gift & 41 & 31.54 \\
\hline Others & 20 & 15.39 \\
\hline Total & 130 & 100.00 \\
\hline
\end{tabular}

Source: Field Survey, 2011

Data in Table 4.6 indicated that majority (31.54\%) of the women vegetable farmers acquired the land they are using for farming through gift. $22.31 \%$ of the women vegetable farmer obtained their land through inheritance, while $15.38 \%$ of the women vegetable farmers acquired their land through purchase, tenancy and other means.

\section{Relationship between Gross Margin and Socio-economic Factors}

Table 4.7: Regression Results of Gross Margin and Socio-economic Factors

\begin{tabular}{|l|l|l|l|}
\hline Variables & Coefficients & Standard error & t-value \\
\hline Constant & 446.37 & 15568.26 & 0.03 \\
\hline $\mathbf{X}_{1}$ (age) & 204.34 & 201.23 & 1.02 \\
\hline $\mathbf{X}_{2}$ (Years of formal education) & 231.94 & 413.26 & $0.56^{*}$ \\
\hline $\mathbf{X}_{3}$ (farming experience) & -118.06 & 102.30 & -1.15 \\
\hline $\mathbf{X}_{4}$ (land ownership) & 504.90 & 780.10 & $0.65^{*}$ \\
\hline $\mathbf{X}_{5}$ (price of basket of vegetable) & 33.85 & 26.92 & 1.26 \\
\hline $\mathbf{X}_{6}$ (cost of chemicals) & 0.91 & 2.87 & $0.32^{*}$ \\
\hline $\mathbf{X}_{7}$ (cost of labour) & 0.53 & 1.41 & $0.38^{*}$ \\
\hline
\end{tabular}

Mean Gross Margin = \# $33047 \quad R^{2}=0.77 \quad{ }^{*}$ means significant at $5 \%$ level

Source: Data Analysis, 2011. 
The regression results obtained from data collected is presented in Table 4.7 above. The $\mathrm{R}^{2}$ (Coefficient of determination) has a value of 0.77 . This shows that independent variables determine about $77 \%$ of variations in the gross margin of women vegetable farmers. Thus, the regression has a good fit to explain the relationship between gross margin and socioeconomic factors of the women vegetable farmers. The mean gross margin is \#33047. Four variables were significant at $5 \%$ level. These are years of formal education, land ownership, cost of chemicals and cost of labour. The discussions under each variable are given below:

Age $\left(\mathbf{X}_{1}\right)$ : The sign on the coefficient of age is as expected. The variable is not statistically significant.

Years of formal education $\left(\mathbf{X}_{2}\right)$ : This variable is rightly signed as it is expected that higher level of education will trigger an increase in the gross margin. The variable is statistically significant at $5 \%$ level.

Farming experience $\left(X_{3}\right)$ : The sign of variable indicated that there is a negative relationship between gross margin and farming experience. This may be due to resistance to new innovations by farmers who had high years of farming experience which will adversely affect their gross margin. The variable is insignificant at $5 \%$ level.

Land ownership $\left(\mathbf{X}_{4}\right)$ : This variable has a positive relationship with gross margin. The variable is statistically significant at $5 \%$ level.

Price of basket of vegetable $\left(X_{5}\right)$ : The coefficient was insignificant at $5 \%$ level, but the sign indicated a positive relationship with gross margin. The higher the price the higher the gross margin.

Cost of chemicals $\left(\mathbf{X}_{6}\right)$ : This variable has a positive relationship with gross margin and is statistically significant at $5 \%$ level. This is because the variable is a strong determinant of gross margin.

Cost of labour $\left(\mathbf{X}_{\mathbf{7}}\right)$ : The cost of labour is statistically significant at $5 \%$ level and has a positive relationship with gross margin. Cost of labour is one of the major production cost.

Table 4.8: Analysis of Variance for Variations in Socio-economic Characteristics of Respondents

\begin{tabular}{|l|l|l|l|}
\hline Model & Mean Square & F-value & Remarks \\
\hline Regression & 47484050.600 & 1.60 & N.S. \\
\hline Residual & 29770885.264 & & \\
\hline Total & & & \\
\hline
\end{tabular}

Source: Data Analysis, 2011

Tabular F-value $=3.92$ at $p=0.05 \quad \mathrm{NS}=$ Not Significant .

The results of analysis of variance in Table 4.8 show that there is no significant difference in the socio-economic characteristics of women vegetable farmers in the study area. This is because F calculated (1.60) is less than F tabulated

Table 4.9: Analysis of Variance for Variations in the Gross Margin of Respondents

\begin{tabular}{|l|l|l|l|}
\hline & Mean Square & F-value & Remarks \\
\hline Between groups & 49653391.88 & 1.57 & N.S. \\
\hline Within groups & 31549370.50 & & \\
\hline Total & & & \\
\hline
\end{tabular}

Source: Data Analysis, 2011

Tabular F-value $=3.92$ at $p=0.05 \quad \mathrm{NS}=$ Not Significant.

The results of analysis of variance in Table 4.9 show that there is no significant difference in the gross margin of women vegetable farmer groups in the study area. This is because $F$ calculated (1.57) is less than F tabulated (3.92).

\section{CONCLUSION}

This study analyzed the effects of socio-economic characteristics of women vegetable farmers on their gross margin in Iwo Zone of Osun State. Data was obtained from respondents with structured interview schedule. Frequencies, Percentages, Means and Standard Deviation were the main descriptive statistics that were employed in the analysis of data. The inferential statistics that were used in the study include Analysis of Variance (ANOVA) and Multiple Regression Analysis. The major findings of the study are: 
(i) Majority (76.15\%) of women vegetable farmers fall between the ages of 41-60 years with a mean age of 50.85 years.

(ii) $66.7 \%$ of women vegetable farmers had primary education.

(iii) All (100\%) of the women vegetable farmers are married

(iv) $\quad 58.46 \%$ of the women vegetable farmers have at least fifteen (15) years of farming experience.

(v) The mean gross margin of women vegetable farmers is \#33047

(vi) Four variables were significant at 5\% level. These are years of formal education, land ownership, cost of chemicals and cost of labour

(vii) There is no significant difference in the socioeconomic characteristics of women vegetable farmers in the study area.

(viii) There is no significant difference in the gross margin of women vegetable farmers group in the study area.

The mean gross margin (\#33047) obtained from the study indicated that vegetable production is an essential income earner for rural women in the study area.

\section{RECOMMENDATIONS}

Based on the findings of the study, the following recommendations are made for sustainable vegetable production by women farmers:

(i) Incentives should be provided to ensure expansion of production and supply of vegetables to markets for consumers.

(ii) Women vegetable farmers should be constituted into co-operative groups which will enable them to have accesses to loans and subsidized inputs for vegetable production.

(iii) Extension services should be provided to update the women farmers in recent global trend in vegetable production.
Adeyemi BT (1992). "Role of Women in Agricultural production in Kwara State" in Agric News, Kwara Agric Development Programme, Ilorin, Kwara State, Nigeria.

Akor R (1990). The role of women in agriculture and constraints to their effective participation in agricultural development in Nigeria. Paper presented at UNDP/ILO/DFRRI Training Workshop on Monitoring and Evaluation of Rural Women in Productive Skills Project.

Badmus MA and Yekinni OT (2011). "Economic Analysis of Exotic Vegetable Production among Urban Fadama Women Farmers in Akinyele Local Government Area Oyo State, Nigeria". International Journal of Agricultural Economics and Rural development 4 (1) 2011.

Charles AO (2009). "Reducing Post harvest Losses of Horticultural Commodities in Nigeria through Improved Packaging" International Union of Food and Science and Institute of Food Technologists.

Janelid I (1975). The role of women in Nigerian agriculture. Rome: FAO.

Mofeke ALE, Ahmada A and Mudiane OJ (2003). "Relationship between yield and seasonal water use for tomatoes, onions, and potatoes grown under fadama irrigation". Asset Series A. 3:35-46.

Patrick M (2010). The Importance of Vegetables Healthy Life Journal.

Sabo E and Zira YD (2009)."Awareness and effectiveness of vegetable technology information packages by vegetable farmers in Adamawa State, Nigeria". African Journal of Agricultural Research Vol. 4 (2), pp. 065-070.

Samanta R K (1994). They reap less than they sow. The Hindu (April), No. 7. Madras: India.

WORDOC (1988). Women in agriculture. African Notes, $\wedge$ (Special Number). Institute of African Studies, Ibadan.

Yemisi $I O$ and AA Mukhtar (2009). "Gender Issues in Agriculture and Rural Development in Nigeria: The Role of Women". Humanity \& Social Sciences Journal $\quad 4 \quad$ (1): $19-30$.

\section{REFERENCES}

